\title{
NATURAL REGENERATION DYNAMICS OF WOODY PLANTS IN THE MARANTACEAE FORESTS OF YOKO RESERVE AND ITS SURROUNDINGS
}

\author{
MBANGILWA, M. M. ${ }^{1}$ - JiANG, L.C. ${ }^{1 *}$ - MBAYU, M. F. ${ }^{2}-$ TAMBWE, L. E. $^{3}-$ BBIDJO, T. V. ${ }^{4}-$ \\ NSHIMBA, S. H. ${ }^{2}$ \\ ${ }^{1}$ Key Laboratory of Sustainable Forest Ecosystem Management-Ministry of Education, School \\ of Forestry, Northeast Forestry University, Harbin 150040, China \\ ${ }^{2}$ University of Kisangani, Kisangani, DR Congo \\ ${ }^{3}$ Higher Institute of Agronomic Studies, Bengamisa, DR Congo \\ ${ }^{4}$ Higher Education Institute of Bunia, Bunia, DR Congo \\ *Corresponding authors \\ e-mail: jlichun@nefu.edu.cn \\ (Received 6 ${ }^{\text {th }}$ Jan 2019; accepted $3^{\text {rd }}$ May 2019)
}

\begin{abstract}
Forest areas occupied by Marantaceae show a significant regeneration deficit because of the bulk of foliar and subterranean biomass of these herbaceous plants. The present study evaluates the regeneration dynamics $(<10 \mathrm{~cm}$ diameter) of Marantaceae forests by counting and identifying preexisting regrowth, then their subsistence rate, and finally comparing the potential of regeneration with that of mixed wood forests and that of the Gilbertiodendron dewevrei forests (De Wild.) J Leonard. At a confidence level of $95 \%$, a highly significant difference $\left(\mathrm{F}=120.40, p<2.2 \mathrm{e}-16^{* * *}\right)$ is observed between the averages. These averages are $68.36 \pm 40.19$ in the Marantaceae of Biaro, 105, $24 \pm 84$ in the Marantaceae of Yoko Forest Reserve, $435.8 \pm 147.3$ in the mixed forests and 620, $16 \pm 175.55$ in the $G$. dewevrei forests at (De Wild.) J Leonard. In addition, regeneration of Marantaceae has a very high mortality rate averaging at $23.22 \%$. This pre-existing deficit and the high mortality rate significantly affects the forest dynamics of the Yoko Forest Reserve and its surroundings. The clear-cut technique of the aboveground and underground biomass of Marantaceae tested during this study is essential for any development of these herbaceous groups, it has increased by an average of $23.5 \pm 7.43 \%$ in the plots of $2 \mathrm{~m}^{2}$.
\end{abstract}

Keywords: aboveground, underground, biomass, Gilbertiodendron dewevrei, Biaro

\section{Introduction}

Regeneration is a vital process in forest ecosystems. It is at the base of the balance and demography of the plant population and the rejuvenation of the stand following the disappearance of mature trees by windfall or exploitation. These populations of the future result either from pre-existing regrowth or vegetative potential, or from preexisting seeds or edaphic seminal potential, and finally, seeds arriving from the outside after opening of the cover or external potential (Alexander, 1982, 1989; N'dja et al., 2010).

Two meanings are attributed to the expression of natural regeneration. The first expresses the process in which the tropical forest reproduces itself naturally. It refers to the meaning of dynamics. The second, which is often used by foresters, corresponds to all the seedlings, strands and seedlings existing in a stand. It refers to the statistics of regeneration potential in a forest stand (Oldeman, 1990; Puig et al., 1989, 1992; Puig, 2001). More than $10 \%$ of the forests in the Yoko Forest Reserve are infested with 
Marantaceae herbaceous plants. In that zone the regeneration of woody trees seems very limited. The foliage biomass of these herbaceous species is screened to limit the substantial penetration of the luminous flux into the soil and their very perennial rhizomes in the basements constitute real obstacles to the flowering of the seedlings in an area intended for sustainable conservation forest resources.

This study evaluates the dynamics of regeneration at counting thresholds $(<10 \mathrm{~cm})$ of Marantaceae forests by counting and identification, then their mortality rate, and finally, compares the regeneration potential of these herbaceous plants with that of mixedwood forests and that of Gilbertiodendron dewevrei forests (De Wild.) J Leonard on the same topological sequence.

\section{Materials and methods}

\section{Study area}

The present study was conducted in the forests around Kisangani, specifically in the Yoko Forest Reserve located in the Tshopo province, the community of BakumuMangongo, Ubundu territory and more particularly in experimental plots of Biaro (Fig. 1), in east of the Democratic Republic of Congo.

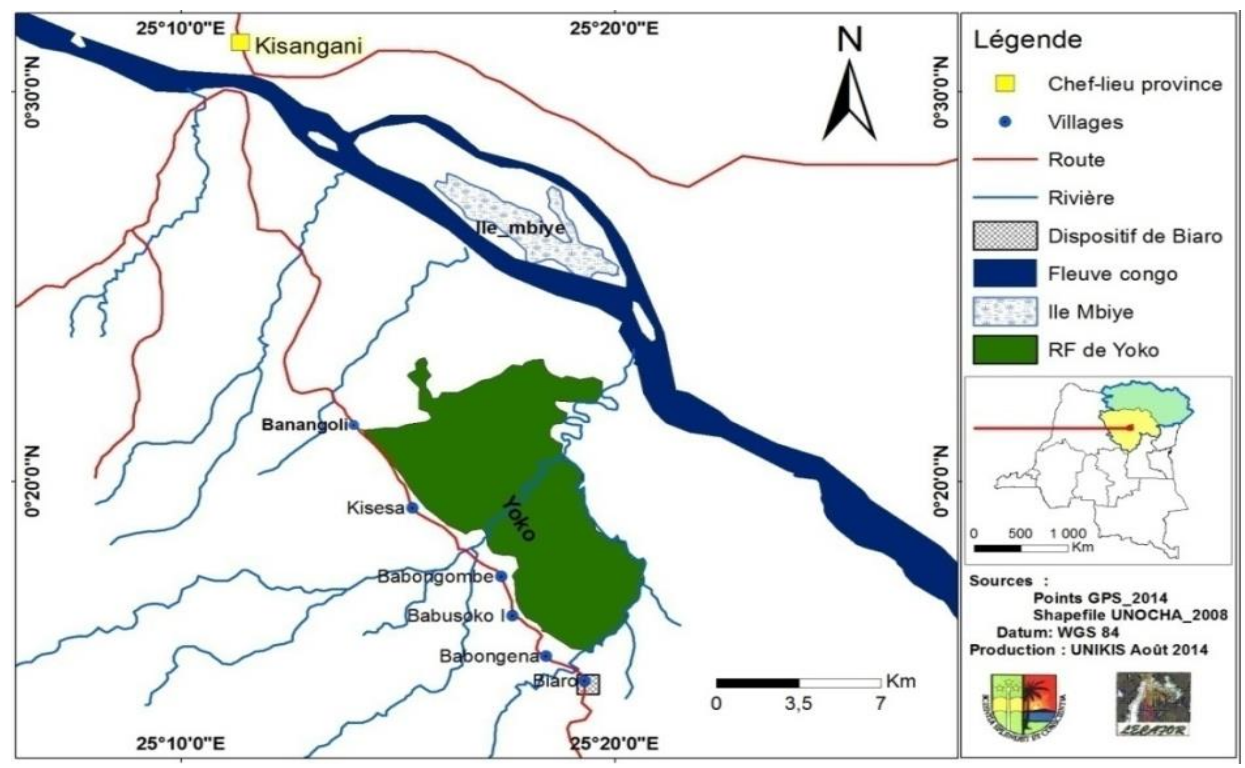

Figure 1. Location of the Yoko Forest Reserve and the Biaro plots

It is governed by the ordinance $n^{\circ} 52 / 104$ of the 28/02/1959 of the Ministry of the Environment, Nature Conservation and Sustainable development. It is a private property of the Congolese Institute for the Conservation of Nature accordance to the ordinance - law no. 75-023 of July 1975 of the Ministry of the Environment establishing a public company of the State for the purpose of managing certain public environmental institutions as modified and supplemented by the ordinance-law $n^{\circ} 78-190$ of May 05, 1988.

The Yoko Forest Reserve is located on North longitude: $00^{\circ} 17^{\prime}$ 59' and East: $025^{\circ} 17^{\prime}$ 4" between 400 and $500 \mathrm{~m}$ altitude. The Biaro device is located $\pm 10 \mathrm{~km}$ south of the Yoko Forest Reserve on North Longitude $00^{\circ} 12.27^{\prime}$ ' ' " and East $025^{\circ} 20.0^{\prime} 4^{\prime \prime}$ between 420-530 
$\mathrm{m}$. The average temperature is $25^{\circ} \mathrm{C}$ and the annual average rainfall is $1750 \mathrm{~mm}$. It is located between 23 and $45 \mathrm{~km}$ points of the road and the Kisangani-Ubundu railway. The Yoko River, which crosses this concession, divides it into two blocks, of which the North block with 3,370 ha and the South block with 3,605 ha represent an overall area of 6,975 ha (Lomba and Ndjele, 1998). Vegetation in the reserve is composed of mixed forest, sometimes sparse, forests of Marantaceae and rattan, monodominant forests of Gilbertiodendron dewevrei (De Wild.) J. Leonard, and secondary forests (Lomba, 2012).

\section{Methods}

The equipment used consists of a vernier caliper to measure seedling diameters, metric ribbons to size plots and study plots, a GPS to collect geographic coordinates. The biological material is made from consisted of woody seedlings less than $10 \mathrm{~cm}$ in diameter. Full counting and identification of vegetative potential at counting threshold of diameter $<10 \mathrm{~cm}$ was carried out in the $50 \mathrm{~m}^{2}$ plots stratified in $10 \mathrm{~m}^{2}$ plots in the Marantaceae of the Yoko Forest Reserve and Biaro. To compare the pre-existing regrowth potential of Marantaceae with that of Gilbertiodendron dewevrei (De Wild.) J. Léonard and mixedwood forests, plots of identical size were delineated in these stands. The geographical coordinates of the sites in study are shown in Table 1.

Table 1. Coordinates and altitudes of the study areas

\begin{tabular}{c|c|c}
\hline Study areas & Informations & Altitude (m) \\
\hline Marantaceae Forest RF Yoko & $\begin{array}{c}\text { N00 } 18^{\prime} 42.6^{\prime}, \\
\mathrm{E} 025^{\circ} 17^{\prime} 31.0^{\prime},\end{array}$ & 435 \\
\hline Marantaceae Forest of Biaro & $\begin{array}{c}\mathrm{N} 00^{\circ} 12^{\prime} 05.9^{\prime}, \\
\mathrm{E} 025^{\circ} 17^{\prime} 20.05^{\prime},\end{array}$ & 456 \\
\hline Mixed forest & $\begin{array}{c}\mathrm{N} 00^{\circ} 18^{\prime} 27.9^{\prime}, \\
\mathrm{E} 025^{\circ} 17^{\prime} 40.4^{\prime},\end{array}$ & 466 \\
\hline Gilbertiodendron dewevrei Forest & $\begin{array}{c}\mathrm{N} 00^{\circ} 18^{\prime} 02.2^{\prime}, \\
\mathrm{E} 025^{\circ} 17^{\prime} 49.9^{\prime},\end{array}$ & 456 \\
\hline
\end{tabular}

Assisted regeneration was tested in the Marantaceae of the Yoko Forest Reserve. The technique consisted of clear cutting of aboveground biomass and rhizome extirpation in plots of $40 \mathrm{~m}^{2}$ stratified in $2 \mathrm{~m}^{2}$ plots. All seedlings were counted and marked. Two months later, a recount was done.

Data processing was based on the few botanical characterization indices (Doucet, 2003):

$$
\begin{gathered}
\text { Relative frequency of a species }=\frac{f \text { requency of a species }}{\sum \text { frequencies of all species }} \times 100 \\
\text { Abundance }(\%)=\frac{\text { Number of individuals of the species }}{\text { Number of individuals of all species }} \times 100 \\
\text { Dominance }(\%)=\frac{\text { Basal area of the species }}{\text { Total basal area }} \times 100 \\
\text { Relative importance: } I_{r}=\frac{D_{r}+D_{0 r}+F_{r}}{3}
\end{gathered}
$$


The annual mortality rate (March 2013 - March 2014) is evaluated from the Madron relationship (1993): $T M(\%)=100 x[1-N t / N o]^{\wedge}(1 / t)$, where: $T M=$ mortality rate, $\mathrm{t}=$ duration of the calculation period, $\mathrm{N}_{0}=$ starting workforce and $\mathrm{N}_{\mathrm{t}}=$ number of survivors after $t$ years. Four plots of $200 \mathrm{~m}^{2}$ divided into plots of $100 \mathrm{~m}^{2}$ were delimited in the East, West and South of the forest reserve of Yoko Biaro were followed.

The comparison of the averages was done by the ANOVA test. As for the ANOVA, Tukey's post-hoc test at $p<0.05$ was used to detect the differences between the different averages taken two by two. The Shapiro-Wilk test was used initially to check the normality of the data. The comparison of the two averages was done by Student's ttest. The comparison of the proportions between the diameter classes was carried out with the test of $\chi^{2}=\sum_{i=1}^{k} \frac{(n i-t i)^{2}}{t i}$., where ni = number of individuals observed in class $\mathrm{i}$; $\mathrm{t}_{\mathrm{i}}=$ number of theoretical individuals in class $\mathrm{i} ; \mathrm{k}=$ class number of the qualitative variable $(\mathrm{k} \geq 2)$ and $\mathrm{i}=$ class number of the qualitative variable $(1 \leq \mathrm{I} \leq \mathrm{k})$.

The different tests and their significance were provided by the $\mathrm{R}$ version 2.10.0 software.

\section{Results}

Potential for woody seedlings of Marantaceae, mixedwood and Gilbertiodendron dewevrei forests (De Wild.) J. Léonard

The average densities of woody seedlings at counting thresholds of $<10 \mathrm{~cm}$ diameter, for a 95\% confidence interval in Marantaceae forests, mixedwood forests and Gilbertiodendron dewevrei (De Wild.) J. Leonard forests are arranged in descending order (Fig. 2): $\quad 69.36 \pm 40.19 \quad 6<105.24 \pm 89<435.8 \pm 147.39<620.16 \pm 170.55$ respectively, in the Marantaceae of the Yoko (MarRFY), the Marantaceae of Biaro (MarBia), the mixed forests and the forests to Gilbertiodendron dewevrei (De Wild.) J. Leonard (FDM and FDG).

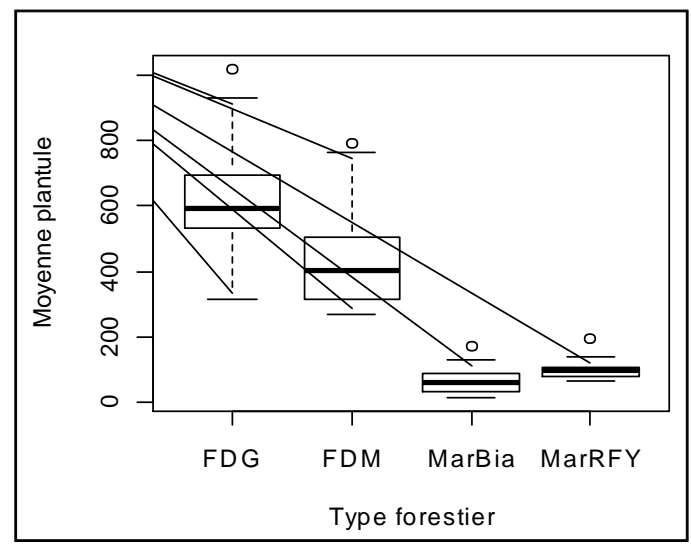

Figure 2. Dispersion of seedling density values of Marantaceae, mixedwood and Gilbertiodendron dewevrei forests (De Wild.) J. Léonard

The highly significant difference is observed between the different groups $\left(\mathrm{F}=120.40, p<2.2 \mathrm{e}-16^{* * *}\right)$, and is not significant between the Yoko Forest Reserve of Marantaceae and the Biaro forest of Marantaceae (Tukey: $p>0.05$ ), highly significant 
between Marantaceae and mixedwood forests and between Marantaceae and Gilbertiodendron dewevrei forests (De Wild.) J. Leonard (Tukey: $p<0.01$ ).

\section{Mortality rate in Marantaceae forests}

The mortality rate is studied in the East, West and South Marantaceae of the Yoko Forest Reserve and at Biaro (Table 2). In each site, two plots of $10 \mathrm{~m}^{2}$ were monitored. A count was made in each plaza on March 10, 2012 and a recount on March 10, 2013.

Table 2. Mortality rate of woody seedlings in Marantaceae forests

\begin{tabular}{c|c|c|c}
\hline \multirow{2}{*}{ Site } & \multicolumn{3}{|c}{ Number of seedlings } \\
\cline { 2 - 4 } & $\mathbf{2 0 1 2}$ & $\mathbf{2 0 1 3}$ & Mortality rate (\%) \\
\hline Ouest Marantaceaa RF Yoko 1 & 136 & 73 & 46.32 \\
Ouest Marantaceaa RF Yoko 2 & 136 & 116 & 14.71 \\
East Marantaceaa RF Yoko 1 & 44 & 26 & 40,91 \\
East Marantaceaa RF Yoko 2 & 94 & 66 & 29.79 \\
South Marantaceaa RF Yoko 1 & 93 & 62 & 29.79 \\
South Marantaceaa RF Yoko 2 & 115 & 93 & 19.13 \\
Biaro 1 Marantaceaa & 130 & 104 & 20 \\
Biaro 2 Marantaceaa & 64 & 61 & 20 \\
\hline Average & $101.5 \pm 34.26$ & $75.14 \pm 28.53$ & $23.22 \pm 12.26$ \\
\hline
\end{tabular}

The mortality rate varies from one site to another. It is higher in the Marantaceae of the Yoko Forest Reserve where it varies from $46.32 \%$ to $4.71 \%$ whereas it varies from $20.00 \%$ to $4.69 \%$ in Biaro.

\section{Specific richness and index of importance of woody seedlings}

The species richness and the importance index (Table 3) calculated in the different sites on equivalent areas equal to $2,500 \mathrm{~m}^{2}$.

Table 3. Temperament and index of importance of woody seedlings of Marantaceae forests

\begin{tabular}{c|c|c|c|c|c|c}
\hline Species & Temperament & $\begin{array}{c}\text { De r } \\
(\boldsymbol{\%})\end{array}$ & $\begin{array}{c}\text { Dor } \\
(\boldsymbol{\%})\end{array}$ & $\begin{array}{c}\text { Fr } \\
(\boldsymbol{\%})\end{array}$ & IVI \\
\hline North Mar & TO & 10.75 & 35.02 & 10.73 & 56.51 \\
\hline Barteria nigritaina Hooker & TO & 9.84 & 10.32 & 9.82 & 29.98 \\
Aidia micrantha (K. Schum.) F. White & TO & 9.61 & 3.02 & 9.61 & 22.24 \\
Scaphopetalum thonneri De Wild. \& Th. Dur. & HNP & 4.58 & 5.43 & 4.58 & 14.59 \\
Pycnanthus angolensis (Welw.) Exell & TO & 5.03 & 3.27 & 5.03 & 13.33 \\
\hline Staudtia kamerunensis Warb & HNP & 10.8 & 8.03 & 10 & 28.83 \\
\hline Marantaceae: Eastern Forest Reserve of Yoko & TO & 8.33 & 7.16 & 8.3 & 23.79 \\
\hline Xylia ghesquierei Robyns & TO & 7.41 & 2.47 & 7.41 & 17.29 \\
Staudtia kamerunensis Warb & TO & 6.17 & 2.25 & 6.17 & 14.59 \\
Crilepisium madagascariense DC & HNP & 5.56 & 1.6 & 5.56 & 12.72 \\
\hline
\end{tabular}




\begin{tabular}{|c|c|c|c|c|c|}
\hline \multicolumn{6}{|c|}{ Marantaceae: Western Forest Reserve of Yoko } \\
\hline Myrianthus preussii Engler & HP & 3.7 & 7.74 & 44.58 & 56.02 \\
\hline Scaphopetalum thonneri De Wild. \& Th. Dur. & TO & 13.51 & 8.05 & 13.51 & 35.07 \\
\hline Pycnanthus angolensis (Welw.) Exell & HNP & 8.5 & 8.95 & 8.5 & 25.95 \\
\hline Turraeanthus africanus (Welw.) Pellegr. & TO & 9.37 & 5.98 & 9.37 & 24.72 \\
\hline Trilepisium madagascariense DC & TO & 5.66 & 2.12 & 5.66 & 13.44 \\
\hline \multicolumn{6}{|c|}{ Marantaceae: Western Forest Reserve of Yoko } \\
\hline Scaphopetalum thonneri De Wild. \& Th. Dur. & TO & 14.99 & 9.97 & 14.73 & 39.69 \\
\hline Rinorea oblongifolia (C.H. Wright) Marquand ex Chipp & HNP & 8.89 & 13.81 & 9.5 & 32.19 \\
\hline Olax gambecola Bailon & TO & 4.73 & 7.65 & 4.65 & 17.03 \\
\hline Alchornea floribunda Mull. Arg & HNP & 4.54 & 3.13 & 4.56 & 12.23 \\
\hline Aidia micrantha (K. Schum.) F. White & TO & 3.55 & 3.97 & 3.49 & 11.01 \\
\hline \multicolumn{6}{|l|}{$\begin{array}{l}\text { Marantaceae Biaro } \\
\end{array}$} \\
\hline Thomandersia hensii De Wild. \& Th. Dur. & TO & 16.67 & 26.34 & 21.66 & 64.67 \\
\hline Rinorea oblongifolia (C.H. Wright) Marquand ex Chipp & HNP & 5.07 & 4.55 & 6.69 & 16.31 \\
\hline Petersianthus macrocarpus (P. Beauv.) Liben & TO & 3.86 & 5.8 & 5.1 & 14.76 \\
\hline Aidia micrantha (K. Schum.) F. White & TO & 3.86 & 5.69 & 4.78 & 14.33 \\
\hline Olax gambecola Bailon & TO & 3.14 & 4.21 & 4.14 & 11.49 \\
\hline
\end{tabular}

$\mathrm{HNP}=$ non-pioneering heliophile, $\mathrm{TO}=$ shade tolerant, $\mathrm{HP}=$ pioneer heliophile, $\mathrm{Dr}=$ relative density, Dor $=$ relative dominance, $\mathrm{Fr}=$ Relative frequency, IVI $=$ importance index

The most important woody seedlings vary from one site to another: Barteria nigritiana Hooke (IVI = 56.51) is more important in the northern Marantaceae, Xylia ghesquierei Robyns (IVI = 28.83) in the Marantaceae of the East, Myrianthus preussii Engler (IVI = 56.02) in the western Marantaceae, Scaphopetalum thonneri De Wild \& Th Dur (IVI = 39.69) in the southern Marantaceae and Thomandersia hensii De Wild. \& Th Dur (IVI $=64.67$ ) is more important in the Marantaceae of Biaro.

The majority of regenerating seedlings in Marantaceae forests are shade tolerant (TO) species. Some light species appear intermittently in the sites (Pycnanthus angolensis (Welw.) Warb., Rinorea oblongifolia (C.H Wild) Marquand ex Chipp, Xylia ghesquierei Robyns and Alchornea floribunda Mull. Arg.

\section{Diametric distribution dynamics of seedlings in Marantaceae forests}

Diameter frequencies (Table 4) by seedling neck diameter class were measured in the Marantaceae of the North, South, East and West of the Yoko Forest Reserve and in Biaro on equivalent areas of $500 \mathrm{~m}^{2}$ stratified in 5 plots $(10 \mathrm{~m} \times 10 \mathrm{~m})$.

The frequency of seedlings per diameter class in five sites is low in classes $>1-1 \mathrm{~cm}$, it goes up a notch in classes 1-2 $\mathrm{cm}$, then an asymmetrical decrease begins to be observed from classes $2-3 \mathrm{~cm}$. The independence test $\chi^{2}$ applied to compare the diametric structures indicates that there is a "site" effect, $\left(\chi^{2}=308.81\right.$, $\mathrm{df}=32$, $p<0.01)$. Calculating the contributions (\%) of $\chi^{2}$ from each diameter class to the total $\chi^{2}$ statistic shows that the classes $(1-2,2-3,>1-1,3-4,6-7$ and 4-5) contribute the most to this difference.

Residue analysis shows that in classes $(1-2 \mathrm{~cm})$, the size of southern Marantaceae individuals is larger and contributes the most to the significant difference of $\chi^{2}$ total obtained. The numbers of the Northern Marantaceae classes 2-3, 4-5 and 6-7 are larger 
and contribute the most to the significant difference of $\chi^{2}$ total obtained. In classes $(>1$ 1) the numbers of western Marantaceae are larger and contribute the most to the significant difference of $\chi^{2}$ total obtained. In the class (3-4), the number of Marantaceae de Biaro individuals is larger and contributes the most to the significant difference of $\chi^{2}$ total obtained. To correctly interpret the degeneracy observed in the diameter classes, the frequencies of the five most important species were followed (Fig. 3).

Table 4. Seedling frequency by site and diameter class $(\mathrm{cm})$

\begin{tabular}{c|c|c|c|c|c}
\hline Dbh (cm) & MarRFYE & MarRFYW & MarRFYS & MarRFYN & MarBia \\
\hline$>1-1$ & 64 & 97 & 38 & 58 & 48 \\
$1-2$ & 142 & 197 & 325 & 110 & 74 \\
$2-3$ & 32 & 57 & 54 & 109 & 63 \\
$3-4$ & 14 & 58 & 26 & 46 & 50 \\
$4-5$ & 17 & 9 & 15 & 35 & 26 \\
$5-6$ & 18 & 8 & 21 & 24 & 16 \\
$6-7$ & 10 & 5 & 5 & 12 & 17 \\
$7-8$ & 7 & 5 & 10 & 12 & 6 \\
$8-9$ & 11 & 6 & 11 & $47.46 \pm 38.13$ & $47.67 \pm 38.13$ \\
\hline Average & $35 \pm 43.79$ & $49.11 \pm 65.57$ & $56.11 \pm 102.01$ & 79.99 & 70.04 \\
CV $(\%)$ & 125.1 & 131.87 & 181.78 & & 23 \\
\hline
\end{tabular}

MarRFYN = Marantaceae North Yoko Forest Reserve, MarRFYE = Yoko Forest Reserve East Marantaceae, MarRFYW = Marantaceae West Yoko Forest Reserve, MarRFYS = South Marantaceae Yoko Forest Reserve, MarBia = Marantaceae of Biaro

It is observed that shade tolerants (TO), which are mainly larger (Table 3), show a positive asymmetry for the most part. This is the case of Barteria nigritiana Hooker, Scaphopetalum thonnerii De Wild \& Th. Dur, Campylospermum sp, Trilepisium madagascariense DC, Turraeanthus africanus (Welw. Ex C.DC.) Pellegr, Olax Gambecola Bailon, Thomandersia hensii De Wild. \& Th. Dur. The species Aidia micrantha (K. Schum.) F. White has, in addition to the structure with positive asymmetry, an irregular frequency. It is the same for Petersianthus macrocarpus ( $\mathrm{P}$. Beauv.) Liben.

Non-pioneer heliophiles (HNP) exhibit variable behavior, sometimes a right-handed distribution or an irregular distribution. This is the case of Pycnanthus angolensis (Welw.) Warb. A symmetrically positive structure is also observed in Rinorea oblongifolia (C.H. Wright) Marquand ex Chipp and Myrianthus preussii Engler, the only pioneering heliophile Alchornea floribunda Mull. Arg presents, unlike all other species, an increase of the numbers in the initial classes $>1-1 \mathrm{~cm}$ and $1-2 \mathrm{~cm}$, which decreases appreciably subsequently, from the intermediate classes. Finally, Xylia ghesquierei Robyns is the only species that has the classical L-shaped structure. A large number of individuals are observed in the initial classes, whereas it decreases as the diameter increases. It is the only species with good regeneration.

\section{Assisted regeneration}

The assisted regeneration (Table 5) was followed in 10 plots of $2 \mathrm{~m}^{2}$ divided into two plots in the West, East and South sites of the Yoko Forest Reserve and Biaro. 


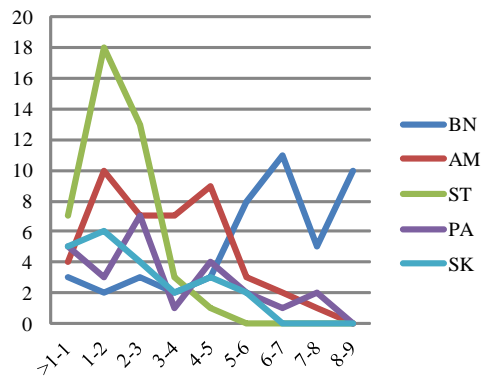

A

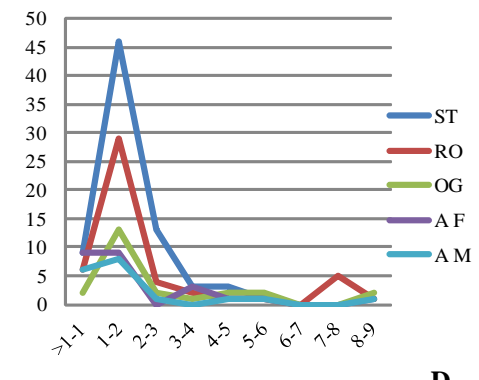

D
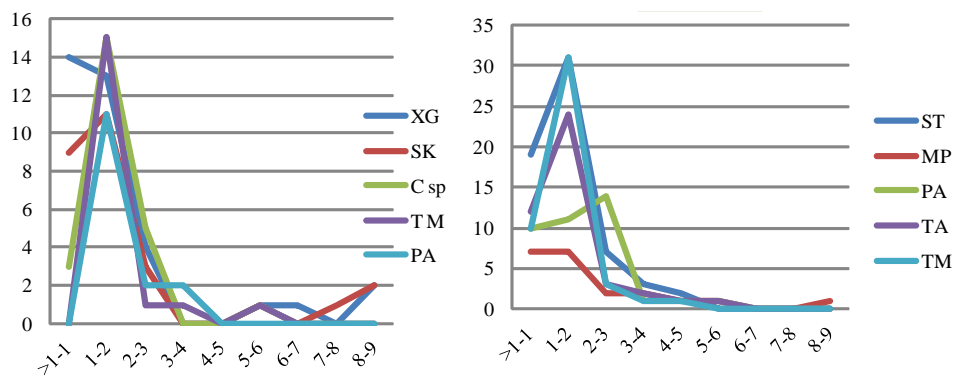

C

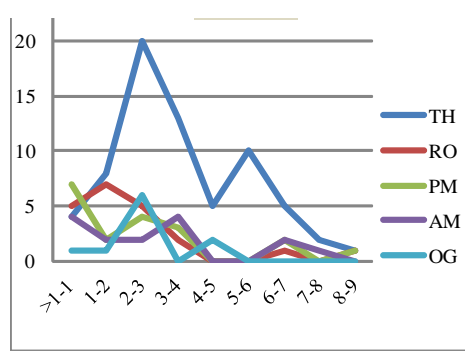

$\mathbf{E}$

Figure 3. Distribution dynamics of woody seedlings (diameter $<10 \mathrm{~cm}$ ) by diameter class of the most important species in Marantaceae forests. (A = Marantaceae North Yoko Forest Reserve,

$B=$ Marantaceae East Yoko Forest Reserve, $C=$ Marantaceae West Yoko Forest Reserve,

$D=$ Marantaceae South Yoko Forest Reserve, $E=$ Biaro Marantaceae, BN = Barteria nigritiana,

$M A=$ Aidia micrantha, $S T=$ Scaphopetalum thonnerii, $S K=$ Staudtia kamerunensis,

$P A=$ Pycnanthus angolensis, $X G=X y l i a$ ghesquierii, $C s p=$ Campylospermum $s p$,

$M P=$ Myrianthus preussii, $T A=$ Turraeanthus africanus $T M=$ Trilepisium madagascariense,

$R O=$ Rinorea oblongifolia $=O G:$ Olax gambecola, $A F=$ Alchornea floribunda

$T H=$ Thomandersia hensii $P M=$ Petersianthus macrocarpus)

Table 5. Regenerative potential (number of seedlings) before and after clearing of the Marantaceae

\begin{tabular}{c|c|c|c}
\hline Quadrant & $\begin{array}{c}\text { Number of seedlings } \\
\text { before thinning }\end{array}$ & $\begin{array}{c}\text { Number of seedlings } \\
\text { after thinning }\end{array}$ & $\begin{array}{c}\text { Number of growing } \\
\text { seedlings }\end{array}$ \\
\hline I & 5 & 30 & 25 \\
II & 19 & 37 & 18 \\
III & 6 & 36 & 30 \\
IV & 18 & 37 & 19 \\
V & 4 & 39 & 35 \\
VI & 13 & 33 & 20 \\
VII & 7 & 31 & 24 \\
VIII & 21 & 55 & 34 \\
IX & 4 & 20 & 19 \\
X & 11 & 25 & 14 \\
\hline Averages & $10.8 \pm 43.51$ & $28.9 \pm 7.69$ & $23.5 \pm 7.43$ \\
\hline
\end{tabular}

After clear-cutting of Marantaceae biomass, the number of woody seedlings increased from an average of $10.8 \pm 43.51$ to $23.5 \pm 7.43$ for a confidence level of $95 \%$. 
The mean independence t-test indicates a highly significant difference between the initial density of the seedlings before clear-cutting and the density of newly planted seedlings after clearcutting $\left(\mathrm{t}=4.2257, \mathrm{df}=18, p<0.0005131^{* * *}\right)$.

\section{Discussion}

\section{Regenerative dynamics, mortality rate and neck diameter structure of seedlings in Marantaceae forests}

The regeneration of woody plants in forests at Marantaceae is very low. For a confidence level of $95 \%$, the average is $105.24 \pm 89$ woody seedlings in the Marantaceae of the Yoko Forest Reserve. This average is nearly 5 times less than that of the forests of Gilbertiodendron dewevrei (De Wild.) J. Leonard and 4 times lower than that of mixed forests. A lower average $(47.67 \pm 36.13)$ was observed in the Marantaceae of Biaro. It is 9 times less than that of $J$. dewevrei (De Wild.) J. Léonard forests and 6 times less inferior to that of mixed forests. A highly significant difference is observed between the different groups (Anova: $\mathrm{F}=120,40, p<2.2 \mathrm{e}-16^{* * *}$ ). Considered in pairs, Tukey's post-hoc comparison of multiple averages test showed a highly significant difference between Marantaceae forests and J. dewevrei (De Wild.) J. Leonard forests and between them mixed forests $(p<0.05 * * *)$.

In addition, an insignificant difference is observed between the Marantaceae of the Yoko Forest Reserve and the Marantaceae of Biaro $(p>0.05)$. Similar results were observed in Odzala where the regeneration density was very low, ie 10 to 70 stems per $100 \mathrm{~m}^{2}$ was observed in the dense Marantaceae forests and 804 to 984 stems per $100 \mathrm{~m}^{2}$ in the dry Marantaceae dry forests (Gillet et al., 2008). This deficit justifies the ability of these herbaceous plants to easily dominate the acquired space to the detriment of woody regeneration for long periods (Lejoly, 1996; Kouka, 2004; Gillet et al., 2008).

Several factors allow Marantaceae to compete with other plants to form persistent monodominant shrubs, namely, (i) the production of a dense leaf layer, (ii) the rapid recovery of rhizomes after each disturbance. These powerful branched rhizomes allow them, from a single strain, to extend considerably the scale of their vegetative apparatus and thus to occupy vast spaces, (iii) they arouse the underground competition and the competition for the light with young plants and (iv) their clonal growth (De Foresta, 1990; Brncic, 2002; Vande Weghe, 2004). This resource rivalry prevents the growth of seedling potential and is the cause of a significant mortality rate of $23.23 \%$ on average in the Marantaceae of the Yoko Forest Reserve and Biaro.

The inhibition impact of these herbaceous plants does not only affect ligneous plants. In Odzala, Bruguière et al. (2000) and Mbayu (2009) observed a decrease in density of small primates at the same time of $40 \%$ with 2.99 troops per $\mathrm{km}$ (all species combined). The heaviest monkeys, Lophocebus albigena (white-cheeked mangabe) and Cercopithecus nictitan (monkey-hog), which preferentially use high forest layers, were more sensitive to canopy opening. Therefore, these impacts suggest that colonization of Marantaceae in a forest area negatively and non-discriminatorily impacts all diversity and may even block the regeneration process (Nepstad et al., 1991).

The frequency degeneration of the pre-existing regrowth in the Marantaceae of the Yoko Forest Reserve and Biaro attests that there is a net "site" effect $\left(\chi^{2}=308.81\right.$, dof $=32, p<0.05)$. Residue analysis after $\chi^{2}$ total showed some classes contributed significantly to this difference, this is the case of classes $1-2 \mathrm{~cm}$ in the South, 2-3 cm, 4- 
$5 \mathrm{~cm}$ and 6-7 $\mathrm{cm}$ and the class $>1-1 \mathrm{~cm}$ west of Yoko Forest Reserve and 3-5 cm class in Biaro. In all cases, it is observed that the extreme classes $1-1 \mathrm{~cm}, 4-5 \mathrm{~cm}$ and $8-9 \mathrm{~cm}$ have a low density compared to the intermediate classes $1-2 \mathrm{~cm}$ and $3-4 \mathrm{~cm}$ ). This positive asymmetry distribution suggests a weak regeneration apparently related to disturbances in the environment (Puig, 2001). Such a structure is different from the structure observed in humid dense forests where the frequencies of individuals in classes ranging from 1 to 10 follow the exponential type law (Puig, 1989 et al, Puig, 1992; N'dja, 2010).

The 5 most important species that were tracked for frequency in the diametric classes showed that shade-tolerant species (TOs) had a positive asymmetric structure. This is the case of Barteria nigritiana DC, Scaphopetalum thonnerii DC, Campilospermum sp, Trilepisium madagascariense DC, Turraeanthus africanus (Welwc ex C.DC.) Pellegr., Olax gambecola Muell. Arg, Thomandersia hensii De Wild. \& Th. Dur. The species Aidia micrantha (K. Schum.) F. White has in addition to the bell structure, an irregular structure. The irregular structure is also observed for the species Petersianthus macrocarpus (P. Beauv.) Liben. On the other hand, non-pioneer heliophiles (HNP) show a very variable behavior, sometimes an irregular structure, this is the case of Pycnanthus angolensis (Welw.) Excell, sometimes a positive asymmetric structure in Rinorea oblongifolia (CHWright) Marquant ex Chipp, Myrianthus preussii Engler and Alchornea floribunda Mull. Arg. have, unlike other heliophiles, an increase in numbers in the initial classes $>1-1 \mathrm{~cm}$ and $1-2 \mathrm{~cm}$ which decrease significantly from intermediate classes. The species Xylia ghesquierei Robyns is the only species with an exponentiallike structure characteristic of dense moist forest species (Rollet, 1974).

The analysis of the structure of a tropical rainforest shows this structural variability according to species, genera or families. This variation reflects in most cases the temperament of the species (Puig, 2001). This behavior is explained by the fluctuation of the luminous flux in the mass of Marantaceae leaves. The ligneous trees show variable behavior in the light. At a young age, they have specific peculiarities relating to their growth and gregariousness. This behavior would lead to types of structures much more varied than the general structure of the L-shaped stand more or less erect, truncated or asymmetric bell, S more or less stretched, or having a spread distribution and almost independent of the diameter (Puig, 1992).

Light plays a fundamental role in the germination of the seminal potential of the soil and the growth of pre-existing recruits. The variations in its intensity and the composition of its spectrum influence the growth, production and productivity of forest ecosystems and indirectly its structure. The decrease in intensity that occurs varies depending on the canopy, the leaf motion and the angle of incidence of the sun's rays (Hall et al., 1981; Puig et al., 1989; Clark, 1990).

\section{Assisted regeneration in Marantaceae forests}

Forests in Marantaceae are considered ecosystems whose regeneration and evolution are extremely slow and deficient due to the almost inextricable coverage of their surface leaf masses and rhizomes in the soil (Brugière et al., 2000; Brncic, 2002). Nevertheless, the clear-cut regeneration of aboveground and underground biomass of these giant herbaceous plants in a few plots during this study increased the density of pre-existing recruits. Overall, for all species combined, an increase in woody seedlings averaged $23.5 \pm 7.4 \%$. This increase suggests that the seminal potential of the soil that was 
dormant beneath the Marantaceae mass of leaves found an optimal luminous flux that allowed it to begin germination (Rey, 1997).

Assisted regeneration was tested in the Marantaceae in Congo Brazza by Gillet in (2013) in order to reinvigorate the deficient regeneration of pre-existing heliophilous species inventoried and identified and then cleared of neighboring competing vegetation. Similarly, nursery seedlings were introduced to maintain linear density in all $4 \mathrm{~m}$. This silviculture has resulted in remarkable performances. The species Canarium schweinfurhii Engl, Ricinodendron heudolotii (Baillon) Pierre ex Hecke, Terminalia superba Engler \& Diels Nauclea diderrichii (De Wild. \& T. Durand) Sea, followed for a year, showed an average growth of between $124 \mathrm{~cm}$ and $154 \mathrm{~cm}$. The most successful planted species was Triplochiton scleroxylon K. Schum, which grew at a height of $95 \mathrm{~cm}$ in a single year.

Numerous interventions based on silvicultural improvement for the management of natural stands have been carried out. These are natural forest interventions in which the silviculturist sought to promote the growth of valuable species in order to valorize and order the forest for its good management (Dupuy, 1989). In Yangambi in the Tshopo Province, several tests were carried out by INERA since colonial times. However, as everywhere in Africa, methods for natural regeneration with more than one canopy opening provided very uncertain results because of the variability of application conditions, the problem of light dosing, the costs of the work, the number of intervention and spread of work over time. But these operations, which remain the only way to develop dense tropical forests, have been abandoned in the process (CTFT, 1989).

In this study, testing of assisted regeneration in Marantaceae forests was not intended to favor any category of species. It was essentially a question of observing the behavior of the potential of the pre-existing recrudescence of the seminal potential in the face of light. The results showed that the forests at Marantaeae abound with an important seminal potential that was waiting for light to initiate their germination. In addition, the potential for pre-existing regrowth exhibited an optimal growth performance after the addition of the luminous flux for two less tests. But it will be necessary to point out that for this prosperous regeneration, it will have to go beyond the carpet of the herbaceous plants which approach them thus to try to slow their development by an optimal closure of the tree cover (Gillet, 2003).

\section{Conclusion}

The impact of Marantaceae forests on woody regeneration in the Yoko Forest Reserve and surrounding area is significant. These herbaceous plants substantially inhibit the regeneration and growth of the potential of pre-existing recrudescence and seminal potential. This impact results in a significant reduction in the density of woody seedlings compared with mixed forests and Gilbertiodendron dewevrei (De Wild.) J. Leonard forests. In addition, under the conditions of highly increased competition, growing recruits have a significant mortality rate of around $23.22 \%$ on average. The few species that regenerates in these herbaceous Marantaceae are mostly shade tolerant and some heliophiles with a structure unfortunately bell or irregular attesting a weak regeneration.

The assisted regeneration test carried out in this study allowed the penetration of an optimal luminous flux which triggered the germination of the seminal potential and 
stimulated the growth of pre-existing recruits. This silvicultural technique is the means of management to reinvigorate regeneration in the Marantaceae forests of the forest reserve.

For future research conducted in and around the Yoko Forest Reserve, we suggested that:

- Studies of permanent assisted regeneration are undertaken based on species growth and silviculture of fast-growing species is practiced and assisted in infested areas.

- Soil and dynamics studies on the annual rate of occupation of the herbaceous species are initiated and conducted.

- Anthracological studies are densified and systematically deepened in the different forest groupings of the Yoko Forest Reserve and surrounding areas to understand the history of the stands in the region.

Agroforestry techniques are popularized and monitored in the riparian communities of the Yoko Forest Reserve and surrounding areas. This integrated land management practice will help contain the practices of clearing that favor the proliferation of hegemonic herbs throughout the region to the detriment of forest dynamics.

\section{REFERENCES}

[1] Alexander, D. Y. (1982): Study of the illumination of the undergrowth of a dense humid forest evergreen (Tai, Ivory Coast). - Acta Oecologica, Oecol. Gener 4(30): 407-447.

[2] Alexander, D. Y. (1989): Dynamics of Natural Regeneration in Dense Forest of Ivory Coast. Study and Theses. - ORSTOM, Paris.

[3] Brncic, T. (2002): Ecology and patch dynamics of Megaphrynium macrostachym (Beth) M. Read (Marantaceae) in the south-west Central African Republic. - Doctoral Thesis. Oxford Forestry Institute and Linacre College, Oxford.

[4] Brugière, D., Bougras, S., Gautier-Hion, A. (2000): Forest dynamics and the colonization process-extinction: fauna-flora relationships in the Marantaceae forests of Odzala National Park. - Ecofac Report 2000: 1-10.

[5] Clark, D. B. (1990): The Role of Disturbance in the Regeneration of Neotropical Moist Forests. - In: Bawa, K., Hadley, M. (eds.) Reproductive Ecology of Tropical Forest Plants. Parthenon, Nashville, TN, pp. 291-305.

[6] CIRAD-CTFT - FRA. 1989. Forester's Memento. Paris: Ministry of Cooperation and Development, 1266 p. (Rural Techniques in Africa) ISBN 2-11-084874-X

[7] De Foresta, H. (1990): Origin and Evolution of Intramayambian Savannahs (R. P. Congo). - In: Lafranchi, R., Schwartz, D. (eds). II. Contributions of Forest Botany. ORSTOM, Paris, pp. 326-335.

[8] Doucet, J. L. (2003): The delicate alliance of forest management and biodiversity in the forests of central Gabon. - PhD Thesis, University Faculty of Agricultural Sciences of Gembloux, Belgium.

[9] Dupuy, B. (1998): Bases for silviculture in tropical moist tropical forest. - Forafri Series, 1998, Document CIRAD-Forêt, Montpellier, pp 1-10.

[10] Gillet, J. F., Missamba-Lola, A. P., Ngalouo, B. (2008): Analysis Report Dynamic Forest Component. - CIB FFEM project "Monitoring the dynamic forest program - agroforestry - wildlife inventories" under the FFEM grant under the financing agreement No CCG 1071.01 A.

[11] Hall, J. B., Swaine, M. D. (1981): Distribution and Ecology of Vascular Plants in a Tropical Rain Forest. Forest Vegetation in Ghana. - W. Junk, The Hague. 
[12] Kouka, L. A. (2004): Regeneration of woody species in forest of Odzala National Park (Congo-Brazzaville). - Acta Botanica Gallica 151(1-3): 293-309.

[13] Lejoly, J. (1996): Use of transect methods for the study of biodiversity in the Ngotto Forest Conservation Area (RCA). - Technical Report: ECOFAC Project, Agreco-CTFT.

[14] Lomba, B.L., Ndjele, M-B. (1998): Using the transect method for the study of phytodiversity in the Yoko Reserve (Ubundu, DR Congo). - Annals (11), Fac. Sci. UNIKIS, 35-46 pp.

[15] Lomba, B. L. (2012): Systems of aggregation and diametric structures according to the temperaments of some species in the permanent devices of Yoko and Biaro (Ubundu, Orientale Province, R. D. Congo). - Thesis F. Sc, University of Kisangani.

[16] Madron, D. L. (1993): Mortality, chablis and the role of holes in sylvigenesis before and after exploitation on the Paracou, French Guiana forestry study system. Ph.D. thesis. ENGREF Nancy / CIRAD-Forest, 203 pp. - annexes.

[17] Mbayu, M. F. (2009): Comparative distribution of Laccosperma secundiflorum (P. Beauv.) Wendl, Eremospatha haullevilleana De Wild. and E. cabrae De Wild. In the REAFOR system of the Yoko Forest Reserve (Eastern Province) DR Congo. - DEA, F. Sc., University of Kisangani.

[18] N'dja, J. K., Ake-Assi, E., Tiebre, M. S. (2010): Plant biodiversity and speed of regeneration of the Sanaimbo classified forest (Côte d'Ivoire). - Science \& Nature 7(2): 195-206.

[19] Nepstad, D., Uhl, C., Serrão, E. A. S. (1991): Recuperation of a degraded Amazonian landscape: forest recovery and agricultural restoration. - Amb. 20: 248-255.

[20] Oldeman, R. A. A. (1990): Forest: Elements of Silvology. - Springer-Verlag, Berlin.

[21] Puig, H. (1992): Forest regeneration. - Adventure Collection, Paris.

[22] Puig, H., Forget, P. M., Sist, P. (1989): Dissemination and regeneration of some trees in the Guyana tropical forest. - Bulletin of French Society 136, Actualité.

[23] Puig. H. (2001): Humid Dense Tropical Forest. - Belin, Paris.

[24] Rey, B. (1997): Consideration of forest dynamics in the context of multifunctional management of woodlands. - XI World Forestry Congress 2: 10, Antalya, Turkey, 13-22 October.

[25] Rollet, B. (1969): Natural regeneration in dense evergreen lowland forest of Venezuelan Guiana. - Woods and Forests of Tropics 124: 19-38.

[26] Vande Weghe, J. P. (2004): Forests of Central Africa, Nature and Man. - Ecofac, Tielt Belgium. 